\title{
Retrospective Analysis of Sheep Scrapie by Western Blotting with Formalin-Fixed Paraffin-Embedded (FFPE) Tissues
}

\author{
Gantsetseg DORJ ${ }^{1,2)}$, Hiroyuki OKADA ${ }^{1)}$, Kohtaro MIYAZAWA ${ }^{1)}$, Kentaro MASUJIN ${ }^{1)}$, Kumiko KIMURA ${ }^{3)}$, \\ Shirou MOHRI ${ }^{1)}$ and Takashi YOKOYAMA ${ }^{1) *}$ \\ 1) Prion Disease Research Center, National Institute of Animal Health, Tsukuba 305-0856, Japan \\ 2) State Central Veterinary Laboratory, Ulaanbaatar 17024, Mongolia \\ ${ }^{3}$ Subtropical Disease Research Division, National Institute of Animal Health, Chuzan, Kagoshima 891-0105, Japan
}

(Received 29 January 2012/Accepted 18 April 2012/Published online in J-STAGE 15 May 2012)

ABSTRACT. An abnormal isoform of prion protein $\left(\mathrm{PrP}^{\mathrm{Sc}}\right)$ was extracted from formalin-fixed paraffin-embedded (FFPE) tissues from sheep and analyzed by western blotting. $\mathrm{PrP}^{\mathrm{Sc}}$ immunoreactivity against anti-PrP monoclonal antibody $\mathrm{T} 2$, which recognizes discontinuous $\mathrm{PrP}$ sequences, differed amongst individual scrapie sheep cases. This may reflect structural differences in $\mathrm{PrP}^{\mathrm{Sc}}$ that have been formalin-fixed prior to their extraction. This study indicates that western blotting by using FFPE tissues is useful for the retrospective analysis of transmissible spongiform encephalopathies in which only formalin-fixed samples are available and in conducting transmissible spongiform encephalopathies surveillance where freezing system is insufficient.

KEY WORDS: FFPE, prion, $\mathrm{PrP}^{\mathrm{Sc}}$, scrapie, WB.

doi: 10.1292/jvms.12-0037; J. Vet. Med. Sci. 74(9): 1207-1210, 2012

Transmissible spongiform encephalopathies (TSEs) are neurodegenerative disorders that affect humans and animals. Bovine spongiform encephalopathy (BSE) in cattle, scrapie in sheep and goats, and Creutzfeldt-Jakob disease in humans are examples of disorders included in this category [15]. Abnormal isoforms of prion proteins $\left(\mathrm{PrP}^{\mathrm{Sc}}\right)$ are major components of pathogenesis [15], and the detection of $\mathrm{PrPSc}$ is the key for TSE diagnosis. Western blotting (WB) and immunohistochemistry (IHC) are routinely used as confirmatory tests. Although WB is a convenient biochemical technique for the detection of $\mathrm{PrPSc}^{\mathrm{Sc}}$, it is not always used because it requires frozen or fresh tissue samples.

Scrapie is caused by many different prion strains, which are characterized by their incubation periods and neuropathology in inbred mice [5]. Strain-specific properties are attributed to the different conformations of $\operatorname{PrP}^{\mathrm{Sc}}[1,2,13$, 18]. The molecular profiles of $\mathrm{PrP}^{\mathrm{Sc}}$ in $\mathrm{WB}$, including the glycoprofiles and molecular weights of proteinase-K (PK)digested $\mathrm{PrP}^{\mathrm{Sc}}$ (PrPcore), are used for the classification of prion strains [3]. As such, it is known that the $\mathrm{PrP}^{\mathrm{Sc}}$ of $\mathrm{BSE}$ and that of scrapie in sheep can be distinguished using WB [14].

In Mongolia, sheep and goats are the major livestock, with hide, skin, cashmere, and meat exports increasing every year. Because there have been no outbreaks of scrapie in Mongolia to date, it is of crucial importance that Mongolian sheep and goats are confirmed negligible of scrapie infec-

\footnotetext{
*Correspondence to: Yokoyama T., Prion Disease Research Center, National Institute of Animal Health, 3-1-5 Kannondai, Tsukuba, Ibaraki 305-0856, Japan.

e-mail: tyoko@affrc.go.jp

(C)2012 The Japanese Society of Veterinary Science
}

tion through consistent surveillance. Unfortunately, it is often difficult to collect and transport frozen brain tissues to laboratories for surveillance, which is also an issue experienced by BSE-affected countries. This is primarily because of geography, with Mongolia being a vast extent of land that includes both deserts to mountainous regions that can be subject to harsh climatic conditions. Nonetheless, pathological examinations are routinely used for the diagnosis of contagious diseases, including rabies and listeriosis.

It has been reported that $\mathrm{PrP}^{\mathrm{Sc}}$ extracted from formalinfixed paraffin-embedded (FFPE) tissues can be detected by WB [12]. Because this technique could enable better TSE surveillance, we tested its usefulness on tissues from sheep scrapie cases for which frozen tissues were unavailable. We have demonstrated that WB analysis by using FFPE will be useful for retrospective analysis of transmissible spongiform encephalopathies.

Brain samples containing scrapie Chandler [7], 79A (TSE Resource Center, Compton, UK), Kanagawa [10], and mouse-adapted BSE [6] affected wild-type mice (ICR) were used. Samples were either stored at $-80^{\circ} \mathrm{C}$ for biochemical analysis, or fixed in $10 \%$ buffered formalin solution and embedded in paraffin for histopathological and immunohistochemical examination. Fixed tissues were treated with $98 \%$ formic acid for $60 \mathrm{~min}$ to reduce their infectivity [17] prior to embedding. Furthermore, 4 FFPE tissues of natural sheep scrapie cases were also examined (Table 1).

For the purification of $\mathrm{PrP}^{\mathrm{Sc}}$ from frozen tissues, brains were homogenized in a buffer containing $100 \mathrm{mM} \mathrm{NaCl}$ and $50 \mathrm{mM}$ Tris- $\mathrm{HCl}$ ( $\mathrm{pH}$ 7.6). The homogenate was mixed with an equal volume of detergent buffer containing 4\% Zwittergent 3-14, 1\% sarkosyl, $100 \mathrm{mM} \mathrm{NaCl}$, and $50 \mathrm{mM}$ Tris$\mathrm{HCl}(\mathrm{pH} 7.6)$ and then incubated with $0.25 \mathrm{mg}$ collagenase. The homogenate was then incubated with $40 \mu \mathrm{g} / \mathrm{ml}$ of PK at 
Table 1. $\quad \operatorname{PrP}^{\mathrm{Sc}}$ detection from FFPE tissues of scrapie sheep

\begin{tabular}{|c|c|c|c|c|c|c|c|}
\hline \multirow{2}{*}{ No. } & \multirow{2}{*}{ Sheep breed } & \multirow{2}{*}{ Year } & \multicolumn{2}{|c|}{$\begin{array}{l}\text { Scrapie } \\
\text { diagnosis }\end{array}$} & \multicolumn{2}{|c|}{$\begin{array}{l}\mathrm{PrP}^{\mathrm{Sc}} \text { detection from } \\
\text { FFPE tissues }\end{array}$} & \multirow{2}{*}{ Remarks } \\
\hline & & & WB & $\mathrm{IHC}$ & $\mathrm{mAb} \mathrm{T} 2$ & mAb SAF84 & \\
\hline 1 & Corriedale & 1991 & $\mathrm{ND}^{\mathrm{a})}$ & + & \pm & ++ & Field case at Fukushima, Fig.2, lane 1 \\
\hline 2 & Suffolk & 1994 & $\mathrm{ND}$ & + & \pm & +++ & Field case at Hokkaido-1, Fig. 2, lane 2 \\
\hline 3 & Suffolk & 1994 & ND & + & \pm & +++ & Field case at Hokkaido-2, Fig. 2, lane 3 \\
\hline 4 & Suffolk & 1999 & ND & + & ++ & +++ & Field case at Tokyo, Fig.2, lane 4 \\
\hline
\end{tabular}

a) Not done (no frozen sample was available).

A

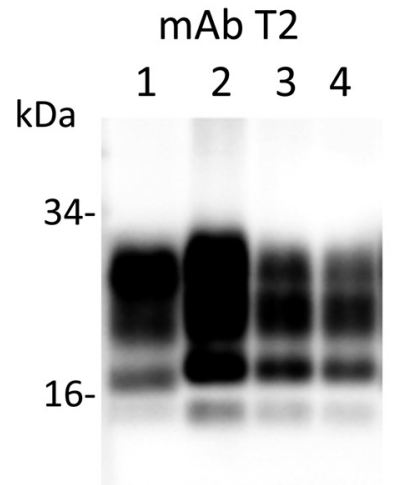

B
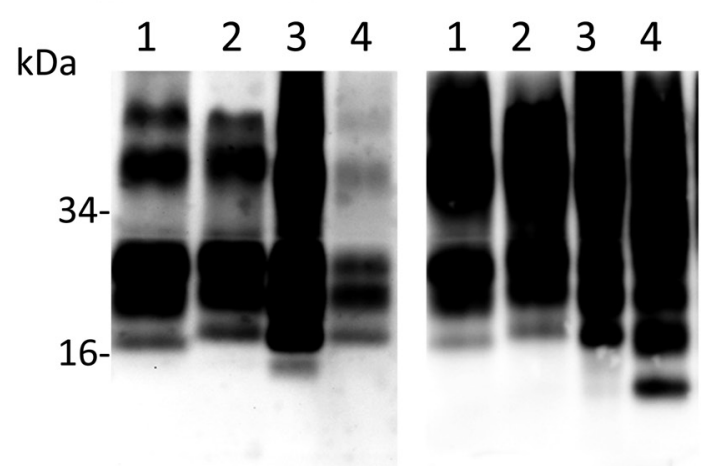

C

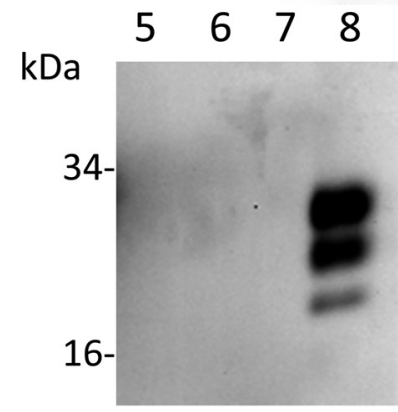

Fig. 1. $\quad \mathrm{PrP}^{\mathrm{Sc}}$ analysis of frozen tissues (A) and FFPE tissues (B) by using western blotting $\mathrm{A}$. $\mathrm{PrPSc}^{\mathrm{Sc}}$ extracted from frozen tissues was detected using mAbs T2 (left panel) and SAF84 (right panel). B. PrPsc extracted from FFPE tissue was detected using mAbs T2 and SAF84. Lane 1, mouse-adapted BSE-affected ICR mice; lane 2, Scrapie Kanagawa strain-affected ICR mice; lane 3, mouse-adapted scrapie 79A strain-affected ICR mice. This sample was examined without formic acid treatment. Lane 4, mouse-adapted scrapie Chandler strain-affected ICR mice. C. Lanes 5-7, FFPE tissues from normal mouse brains. Lane 8, $\mathrm{PrPSc}^{\mathrm{Sc}}$ from mouse-adapted scrapie (frozen tissue). $37^{\circ} \mathrm{C}$ for $30 \mathrm{~min}$. PK digestion was terminated using $2 \mathrm{mM}$ 4-(2-aminoethyl)-benzenesulfonyl fluoride hydrochloride (Pefabloc; Roche Diagnostics). The sample was mixed with 2-butanol:methanol (5:1) and centrifuged at 20,000 $\times g$ for $10 \mathrm{~min}$. The final pellet was analyzed using WB.

The protocol for $\mathrm{PrP}^{\mathrm{Sc}}$ extraction from FFPE tissues was followed as reported previously [8] with minor modifications. Briefly, a section from each FFPE tissue block (PET block) was collected into a $1.5-\mathrm{m} l$ microcentrifuge tube. To each tube, $150 \mu l$ of buffer (50 mM Tris, $1 \mathrm{mM}$ EDTA and $0.5 \%$ Tween $20, \mathrm{pH} 7.5$ ) was added. The tube was incubated at $100^{\circ} \mathrm{C}$ for $10 \mathrm{~min}$ and was then immediately frozen with cold ethanol for $5 \mathrm{~min}$. This process was repeated once, and the tubes were then incubated for additional $10 \mathrm{~min}$ at $100^{\circ} \mathrm{C}$. The sample was then immediately centrifuged at $20,000 \times g$ for $15 \mathrm{~min}$ to separate the paraffin from the buffer. The tissue pellets and aqueous layer were transferred to another tube, and $150 \mu \mathrm{l}$ of detergent buffer containing $4 \%$ Zwittergent $3-14,1 \%$ sarkosyl, $100 \mathrm{mM} \mathrm{NaCl}$, and $50 \mathrm{mM}$ Tris- $\mathrm{HCl}$ (pH 7.6) was added. The pellet was dispersed by sonication and mechanical shearing by using a 27 -gauge needle. The sample was then mixed with PK to a final concentration of $50 \mu \mathrm{g} / \mathrm{ml}$ and incubated at $37^{\circ} \mathrm{C}$ for $30 \mathrm{~min}$. Digestion was stopped by adding $1 \mathrm{mM}$ of Pefabloc. The sample was mixed with 2-butanol:methanol (5:1) and centrifuged at 20,000 $\times$ $g$ for $10 \mathrm{~min}$. The final pellet was analyzed using WB as described previously [9]. The PrP signal was detected using either anti-PrP mAb SAF84 (SPI-Bio, Montigny le Bretonneux, France) and T2 [16], which react against epitopes 160-170 of human PrP sequences and 163-168 of murine PrP sequences, respectively.

WB analysis of $\mathrm{PrP}^{\mathrm{Sc}}$ from frozen tissues of wild-type mice is shown in Fig. 1A, and the 2 mAbs showed a typical $\mathrm{PrP}^{\mathrm{Sc}}$ banding pattern. $\mathrm{PrP}^{\mathrm{Sc}}$ was detected in all the FFPE tissue samples that were examined using both mAbs (Fig. 1B). The molecular weight of $\mathrm{PrP}^{\mathrm{Sc}}$ from BSE-affected wildtype mice was lower than that of samples from scrapie (Fig. 1, lane 1). Although the molecular weights of PrPcore from FFPE tissues were consistent with those of $\mathrm{PrP}^{\mathrm{Sc}}$ from frozen tissues for both T2 and SAF84, the glycoform profile of PrPcore from FFPE tissues was resembled but not consistent with that of frozen tissues (Fig. 1A). A $\sim 14 \mathrm{kDa} \mathrm{PrP}^{\mathrm{Sc}}$ fragment was detected using mAb SAF84 in the FFPE tissue of Chandler-affected mice (Fig.1B, lane 4), but this truncated fragment was not detected during the analysis of frozen tissues (Fig. 1A, lane 4). Formalin fixation influenced PK 
A

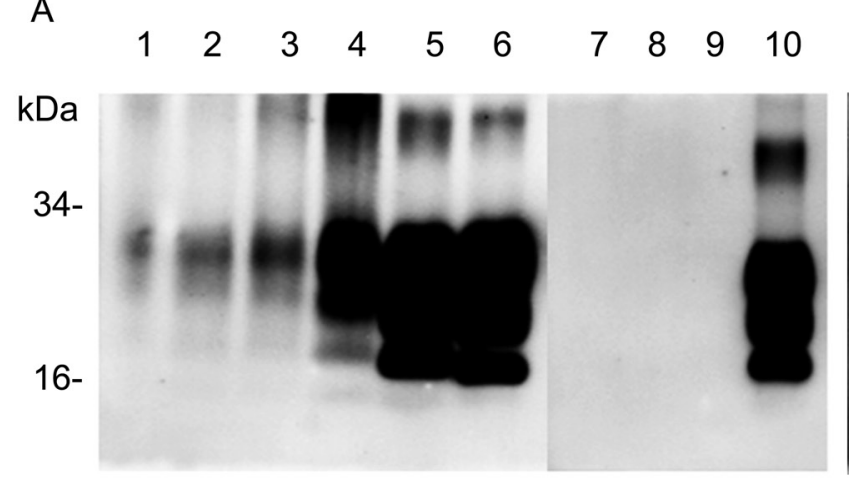

B

$\begin{array}{llllll}1 & 2 & 3 & 4 & 5 & 6\end{array}$

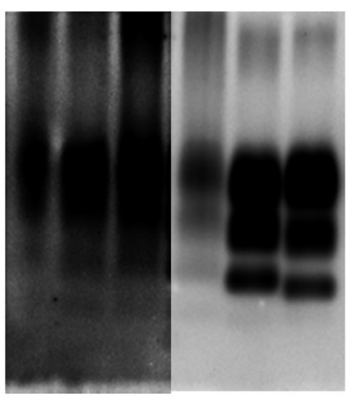

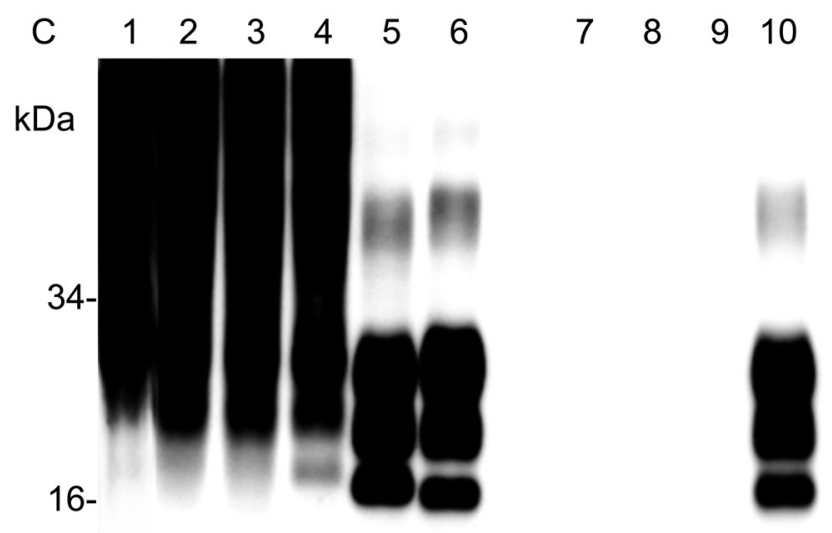

Fig. 2. Comparison of immunoreactivity of $\mathrm{PrP}^{\mathrm{Sc}}$ extracted from FFPE tissue of natural scrapie A. $\mathrm{PrP}^{\mathrm{Sc}}$ extracted from FFPE tissue of natural scrapie was detected using $\mathrm{mAb}$ T2. B. The same membrane was exposed longer time to visualize the unglycosylated $\mathrm{PrP}^{\mathrm{Sc}}$ band. C. The same sample was analyzed using mAb SAF84. Lane 1, field scrapie case of 1991; lanes 2 and 3, field scrapie case of 1994; lane 4, field scrapie case of 1999; lanes 5 and 10, PrPSc extracted from typical scrapie sheep brain (frozen tissue); lane 6, $\mathrm{PrP}^{\mathrm{Sc}}$ from BSE-affected cattle brain (frozen tissue); lanes 7-9, TSEnegative sheep brain samples.

digestion of $\mathrm{PrP}^{\mathrm{Sc}}$ and producing some $\mathrm{PrP}^{\mathrm{Sc}}$ in a partially digested truncated form. Furthermore, strong signals of $\sim 40$ $\mathrm{kDa}$ were detected for all the $\mathrm{PrP}^{\mathrm{Sc}}$ from the FFPE tissues that were examined using SAF84 (Fig. 1B). Formalin fixation induces alkylation of amino residues and cross-linking between bio-molecules. Though the precise mechanisms are obscure, these phenomena may cause by this cross-linking. No PrP signals, either low- or high-molecular weight, were detected in TSE-negative FFPE tissue samples (Fig. 1C).

Then, we examined the $\mathrm{PrP}^{\mathrm{Sc}}$ detection in FFPE tissues from natural sheep scrapie. $\mathrm{PrP}^{\mathrm{Sc}}$ was extracted from FFPE tissue samples obtained from 2 breeds of sheep having scrapie (Suffolk and Corriedale). These samples were fixed between 1991 and 1999 and stored at room temperature. The $\mathrm{PrP}^{\mathrm{Sc}}$ signal was clearly detected in 1 sample (Case No. 4 ), while a weak positive signal was detected in the other 3 samples (Case Nos. 1-3) by using mAb T2 (Table 1, Fig
2A). In contrast, all the examined samples showed a strong positivity for mAb SAF84 (Table 1, Fig. 2C). The molecular weights of the PrPcore from the 4 natural scrapie cases were similar to those of typical scrapie (Fig. 2B). No PrP signal was detected in the FFPE tissue samples obtained from healthy sheep (Fig. 2).

We have shown that $\mathrm{PrP}^{\mathrm{Sc}}$ can be extracted from FFPE tissues [8, 11]. In this study, we used 2 different mAbs. $\operatorname{PrP}^{\mathrm{Sc}}$ from FFPE tissues of scrapie sheep have different immunoreactivities against $\mathrm{mAb} \mathrm{T} 2$, which recognizes discontinuous sequences at PrP163-168 [16]. We concluded that the different immunoreactivities of $\mathrm{PrPSc}^{\mathrm{Sc}}$ in FFPE tissues were not associated with the sheep breed or sample storage time but may be potentially associated with their conformational differences. Our results showed the possibility that immunoreactivity of $\mathrm{PrP}^{\mathrm{Sc}}$ from FFPE tissues might be associated with prion strain diversities in sheep. 
The molecular weights of all the PrPcore extracted from FFPE tissues of natural scrapie cases were similar to those of typical scrapie but different from those from BSE (Fig. 2B). This result indicates that these scrapie cases occurred independently of BSE; however, it is important to note that the origin of BSE has not been identified and sheep scrapie has been considered as a candidate of origin. Furthermore, the potential presence of BSE in small ruminants is cautioned, and a BSE case in a goat has been reported [4]. To investigate the relationship between BSE and scrapie, characterization of individual prions is necessary.

This technique could detect $\mathrm{PrP}^{\mathrm{Sc}}$ from FFPE tissues that were kept more than 10 years. Our study showed that WB analysis by using FFPE will be useful for retrospective analysis in which only formalin-fixed samples are available and in conducting TSE surveillance where freezing system is insufficient.

ACKNOWLEDGMENTS. We thank Yurie Komine, JICA officer, for her kind assistance. We also thank Naoko Tabeta, Naomi Furuya, and Ritsuko Miwa for their technical assistance and Reiko Takeuchi and Junko Yamada for their general assistance. This study was supported by funds for the JICA training course "Veterinary Research Diagnosis" and a BSE control program overseen by the Ministry of Agriculture, Forestry, and Fisheries, Japan. We also thank the staff of the Prion Disease Research Center of the National Institute of Animal Health for their critical comments.

\section{REFERENCES}

1. Aguzzi, A. 2004. Understanding the diversity of prions. Nat. Cell Biol. 6: 290-292. [Medline] [CrossRef]

2. Bessen, R. A. and Marsh, R. F. 1992. Biochemical and physical properties of the prion protein from two strains of the transmissible mink encephalopathy agent. J. Virol. 66: 2096-2101. [Medline]

3. Collinge, J., Sidle, K. C., Meads, J., Ironside, J. and Hill, A. F. 1996. Molecular analysis of prion strain variation and the aetiology of 'new variant' CJD. Nature 383: 685-690. [Medline] [CrossRef]

4. Eloit, M., Adjou, K., Coulpier, M., Fontaine, J. J., Hamel, R., Lilin, T., Messiaen, S., Andreoletti, O., Baron, T., Bencsik, A., Biacabe, A. G., Beringue, V., Laude, H., Le Dur, A., Vilotte, J. L., Comoy, E., Deslys, J. P., Grassi, J., Simon, S., Lantier, F. and Sarradin, P. 2005. BSE agent signatures in a goat. Vet. Rec. 156: 523-524. [Medline]

5. Fraser, H. and Dickinson, A. 1968. The sequential development of the brain lesions of scrapie in three strains of mice. J. Comp. Pathol. 78: 301-311. [Medline] [CrossRef]

6. Hayashi, H. K., Yokoyama, T., Takata, M., Iwamaru, Y., Imamura, M., Ushiki, Y. K. and Shinagawa, M. 2005. The N-terminal cleavage site of $\mathrm{PrP}^{\mathrm{Sc}}$ from $\mathrm{BSE}$ differs from that of $\mathrm{PrP}^{\mathrm{Sc}}$ from scrapie. Biochem. Biophys. Res. Commun. 328: 1024-1027. [Medline] [CrossRef]

7. Iwamaru, Y., Takenouchi, T., Ogihara, K., Hoshino, M., Takata, M., Imamura, M., Tagawa, Y., Hayashi-Kato, H., Ushiki-Kaku, Y., Shimizu, Y., Okada, H., Shinagawa, M., Kitani, H. and Yokoyama, T. 2007. Microglial cell line established from prion protein-overexpressing mice is susceptible to various murine prion strains. J. Virol. 81: 1524-1527. [Medline] [CrossRef]

8. Kunkle, R. A., Nicholson, E. M., Lebepe-Mazur, S., Orcutt, D. L., Srinivas, M. L., Greenlee, J. J., Alt, D. P. and Hamir, A. N. 2008. Western blot detection of $\mathrm{PrP}^{\mathrm{Sc}}$ in archived paraffinembedded brainstem from scrapie-affected sheep. J. Vet. Diagn. Invest. 20: 522-526. [Medline] [CrossRef]

9. Masujin, K., Matthews, D., Wells, G. A., Mohri, S. and Yokoyama, T. 2007. Prions in the peripheral nerves of bovine spongiform encephalopathy-affected cattle. J. Gen. Virol. 88: 1850-1858. [Medline] [CrossRef]

10. Masujin, K., Shu, Y., Okada, H., Matsuura, Y., Iwamaru, Y., Imamura, M., Mohri, S. and Yokoyama, T. 2009. Isolation of two distinct prion strains from a scrapie-affected sheep. Arch. Virol. 154: 1929-1932. [Medline] [CrossRef]

11. Nicholson, E. M. 2011. Enrichment of $\mathrm{PrP}^{\mathrm{Sc}}$ in formalin-fixed, paraffin-embedded tissues prior to analysis by Western blot. $J$. Vet. Diagn. Invest. 23: 790-792. [Medline] [CrossRef]

12. Nicholson, E. M., Kunkle, R. A., Hamir, A. N., Lebepe-Mazur, S. and Orcutt, D. 2007. Detection of the disease-associated isoform of the prion protein in formalin-fixed tissues by Western blot. J. Vet. Diagn. Invest. 19: 548-552. [Medline] [CrossRef]

13. Peretz, D., Scott, M. R., Groth, D., Williamson, R. A., Burton, D. R., Cohen, F. E. and Prusiner, S. B. 2001. Strain-specified relative conformational stability of the scrapie prion protein. Protein Sci. 10: 854-863. [Medline] [CrossRef]

14. Pirisinu, L., Migliore, S., Di Bari, M. A., Esposito, E., Baron, T., D'Agostino, C., De Grossi, L., Vaccari, G., Agrimi, U. and Nonno, R. 2011. Molecular discrimination of sheep bovine spongiform encephalopathy from scrapie. Emerg. Infect. Dis. 17: 695-698. [Medline]

15. Prusiner, S. B. 1991. Molecular biology of prion diseases. Science 252: 1515-1522. [Medline] [CrossRef]

16. Shimizu, Y., Kaku-Ushiki, Y., Iwamaru, Y., Muramoto, T., Kitamoto, T., Yokoyama, T., Mohri, S. and Tagawa, Y. 2010. A novel anti-prion protein monoclonal antibody and its single-chain fragment variable derivative with ability to inhibit abnormal prion protein accumulation in cultured cells. Microbiol. Immunol. 54: 112-121. [Medline] [CrossRef]

17. Taylor, D. M., Brown, J. M., Fernie, K. and McConnell, I. 1997. The effect of formic acid on BSE and scrapie infectivity in fixed and unfixed brain-tissue. Vet. Microbiol. 58: 167-174. [Medline] [CrossRef]

18. Telling, G. C., Parchi, P., DeArmond, S. J., Cortelli, P., Montagna, P., Gabizon, R., Mastrianni, J., Lugaresi, E., Gambetti, P. and Prusiner, S. B. 1996. Evidence for the conformation of the pathologic isoform of the prion protein enciphering and propagating prion diversity. Science 274: 2079-2082. [Medline] [CrossRef] 